\title{
The Project Activities of the Renewable Energy Resources Use in the Republic of Serbia
}

\author{
Larisa Jovanović, Lazar Cvijić \\ ALFA University, Belgrade, Serbia \\ e-mail: larisa.jovanovic@alfa.edu.rs \\ Cite as: Jovanovic, L., Cvijic, L., The Project Activities of the Renewable Energy Resources Use in the Republic of \\ Serbia, J. sustain. dev. energy water environ. syst., 2(3), pp 234-242, 2014, DOI: \\ http://dx.doi.org/10.13044/j.sdewes.2014.02.0019
}

\begin{abstract}
With the ratification of the Energy Community of Southeast Europe countries (14th July 2006) the Republic of Serbia, among other things, accepted the obligation to adopt and implement a plan of applying the Directive 2001/77/EC about promoting the production of electrical energy from renewable energy sources. The projects of the renewable energy resources use have a positive impact on the environment, in particular about the mitigation of global climate change and local environmental sustainability.
\end{abstract}

\section{KEYWORDS}

Renewable energy resources, Small hydropower plants, Landfill biogas, CDM projects, Republic of Serbia.

\section{INTRODUCTION}

The planned gross electricity production in the Republic of Serbia in 2013 was 37,649 TWh, which is $2 \%$ higher than the estimated production in 2012 . The structure of the electricity production is as follows: thermal power plants: $28,150 \mathrm{TWh}(75 \%)$, hydro power plants: 9,116 TWh (24\%), others (including industrial power plant, wind and solar power plants): $1 \%$. The main fuel is coal, primarily lignite or brown coal. The domestic production of electricity almost entirely meets the demand. Planned production of heat in 2013 was 34,401 TJ. Thermal power plants (6\%), thermal-heating stations (5\%), industrial power plants $(25 \%)$ and heating plants $(64 \%)$ participate in the structure of the production. Most of the power plants are older than 40 years and it is urgent to revitalize the existing capacities.

The Republic of Serbia started implementation of the commitments under the Kyoto Protocol [1] for the use of renewable energy sources [2]. In accordance with the National Strategy for Sustainable Development [3] and the Law on the ratification of the amendment to Annex B of the Kyoto Protocol [4], priority policy measures to mitigate the effects of climate change have been identified [5]. In order to improve the risk management system in accordance with the Plan of Spatial Planning of Serbia for the period 2010-2020 year [6], the Ministry of Infrastructure and Energy of the Republic of Serbia prepared a National strategy for the implementation of the Clean Development Mechanism (CDM) projects in the Republic of Serbia. The National strategy for the inclusion of the Republic of Serbia in CDM projects for waste disposal was adopted in February 2010. The Strategy contains information on total assets and priorities for the implementation of CDM projects in the Republic of Serbia [7]. In 2011, the first report

\footnotetext{
* Corresponding author
} 
was adopted by the Republic of Serbia [8] for the obligations of the United Nations Framework Convention on Climate Change $[8,9]$.

In February 2013 the Serbian government has adopted a draft law on energy efficiency, which covers all aspects that affect the costs of municipalities. The new Energy Law clearly defines the privileged electrical and thermal energy producers with the right to subsidies and benefits. The energy producers mentioned in the Law are those which use the renewable energy sources (biogas, landfill gas, wind...) and at the same time produce electrical and thermal (cooling) energy, while fulfilling conditions with respect to energy efficiency and environmental protection.

The National Action Plan for Renewable Energy has received the endorsement of the Energy Community in accordance with the development plan of Serbia until 2020. The Republic of Serbia has committed itself to increasing the share of renewable energy in total energy consumption to $27 \%$ by 2020 [10]. 2015 will be the first reference point for judging the success of control measures in the area of increasing the use of renewable energy sources. As matters stand at the end of 2015, we should expect the trend of further development of renewable energy projects.

In the framework of the German model, local communities will be encouraged to become owners of wind generators to produce electricity. Standard contracts for the purchase of electricity from renewable energy sources will also be accepted.

Serbia expects two billion dollars of investment projects in renewable energy over the next seven years in order to introduce new green energy capacity (up to 1,092 MW). These include wind farms with the capacity of $500 \mathrm{MW}$, hydropower plants (200 MW), biomass processing plants (100 MW) and the plants using other sources of energy (192 MW), which will help stabilize the power grid, to create jobs for people in the green industry sector and prevent environmental problems.

\section{THE CDM PROJECTS IN SERBIA}

The National Authority for the implementation of projects under the Clean Development Mechanism in the Republic of Serbia was formed by the Ministry of Environment and Spatial Planning of the Republic of Serbia. It is responsible for issuing permits to work on projects under the clean development.

The main criteria for participation in CDM projects are:

- Ratification of the Kyoto Protocol;

- Participation in the project on a voluntary basis;

- Establishment of a national authority for the implementation of CDM projects under Kyoto Protocol.

The use of renewable energy sources in the energy sector of the country is an important indicator of sustainable development and energy efficiency [11-13].

To encourage development and investment in the energy sector and meet its obligations under the Energy Community of South East Europe, the Serbian government has adopted a number of regulations, including:

- Establishing a system of feed-in tariffs in which the Serbian government will subsidize the cost of renewable electricity;

- Defining the requirements for the status of privileged power producers that use renewable energy sources for electricity generation.

The system of incentives is thoroughly regulated by the Regulation on incentives for the privileged electrical energy producers, which entered into force on February 4, 2013 [14]. In particular, feed-in tariffs for electrical energy depend on the plants and installed capacity. For hydro power plants, this tariff varies between 5.9 and $12.40 \mathrm{c} € / \mathrm{kWh}$, for 
biogas plants, $12.31-15.66 \mathrm{c} € / \mathrm{kWh}$ and power plants using landfill gas and gas from the plants for the treatment of municipal wastewater, $6.91 \mathrm{c} € / \mathrm{kWh}$.

Unfortunately, the production of energy from biomass, which can be regarded as a very promising source of renewable energy in Serbia is still limited to the production of pellets from waste in agroforestry and agroindustry [15]. Serbia has significant potential for the production of raw material for processing into biodiesel, which is estimated at about $10 \%$ of the total area of arable land. This area can provide enough raw materials for the production of 210 to 250 thousand tonnes of biodiesel a year to replace about 13-16\% of fossil diesel fuel in Serbia.

However, Serbia has not adjusted production of biodiesel during 2013. Its production and use are not competitive when compared with the price of mineral diesel fuel. Biodiesel is produced in Serbia in private workshops, in handicraft installations for the needs of entrepreneurs.

A key condition for the large-scale production and use of biodiesel in Serbia will be the introduction of economic measures that will enable biodiesel to be competitive compared to the prices of mineral diesel. The most important measure is the total or partial exemption from the excise tax on biodiesel. A particular problem is the unregulated market of oilseeds, which is characterized by fluctuations in the price and limitations of areas under oilseeds.

The first factory for the production of biogas from biomass in Serbia was built at the end of 2012 in Vrbas. The owner of the factory will sell electricity for 12 years to the public supplier at a price of $12.31 \mathrm{c} € / \mathrm{kWh}$.

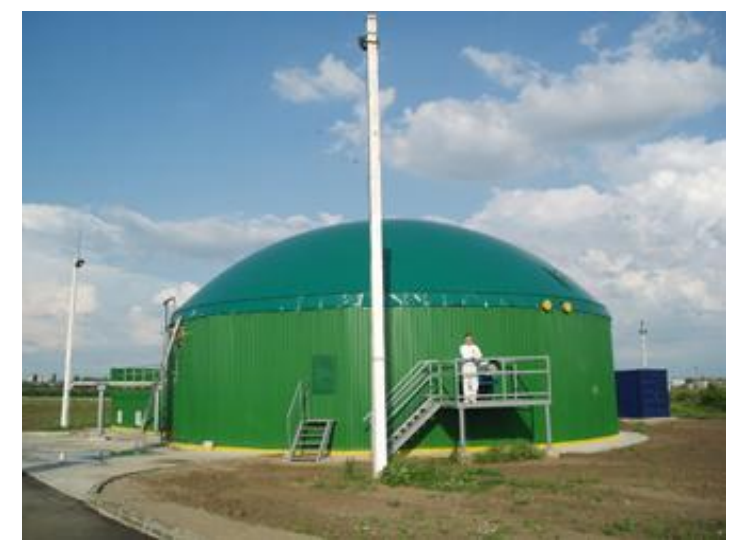

Figure 1. First in the RS factory biogas in Vrbas

\section{BIOGAS FROM LANDFILLS}

In industrial countries, between $300-400 \mathrm{~kg}$ of waste is produced per person annually. The waste is collected and disposed in safe and sanitary landfills which implies the protection of underground waters, and also air protection from unclean and dangerous landfill gas. The landfill gas is created by the degradation of organic materials under the influence of microorganisms in anaerobic conditions. In the middle of the landfill there is an overpressure, so landfill gas is released into environment. An average content of the landfill gas is $35-60 \%$ of methane, $37-50 \%$ of carbon dioxide, and in small quantities we can trace carbon-monoxide, nitrogen, hydrogen sulphide, fluorine, chlorine, aromatic hydrocarbons and other gases in traces. On the basis of the stated content of landfill gases, we can see that this gas is very harmful to environment, especially to living organisms and infrastructural objects in the close vicinity of landfills, because methane is 
very explosive under certain conditions. Methane is 21 times more harmful to climate and ozone layer than carbon dioxide, which means that 1 tonne of methane damages ozone layer (greenhouse effect) as 21 tonnes of carbon dioxide. In order to eliminate the negative effects of uncontrollable expansion of landfill gas, we perform planned collection and forced gas direction towards combustion sites. It allows faster stabilisation of fresh landfill parts, decrease of the underwater contamination, and it allows the use of energy produced in a landfill (heating, hot water, electricity, etc.).

The legal obligation of collecting and flaring landfill gas will be the right solution: combustion gas for energy purposes while creating economic benefits [16].

Benefits from the air pollutants reduction make a valuable contribution to sustainable development [17].

This concept implies placing vertical perforated pipes in the body of the landfill (wells, probes) and their horizontal connection. Through a compressor plant the landfill gas is sucked, compressed, dried and directed towards the gas motor. For security reasons, the installation of a high-temperature torch is recommended, because it flares the excess gas.

The landfill gas with an average content of methane of $50 \%$ has a lower thermal value in the range of $5 \mathrm{kWh} / \mathrm{m}^{3}$, which makes it good fuel for gas engines specially designed for this purpose.

The gas engine drives a generator to produce the more valuable electricity. Through the heat exchanger, we obtain the heat energy from the water that cools the engine and lubricating oil, and also from the exhaust gases. It is possible to attain a high degree of beneficial effects with the combination of electrical and thermal energy (electrical $40 \%$, thermal 43\%). This means that, from $1 \mathrm{~m}^{3}$ of landfill gas, we get $2 \mathrm{kWh}$ of electrical energy and $2.15 \mathrm{kWh}$ of thermal energy. The produced electrical energy is used for our own purposes, or it is directed into the electrical network. The produced heat is used at landfills for the production of hot water, or in conservatories where early vegetables and flowers are produced. It is also used in industrial plants, in the vicinity of landfills, or for heating of apartments. Implementation of the CDM in the dumps in the cities of Uzice, Cacak and Pozega, includes the preparation of three landfills for closure procedure.

The added value of the project is to enable the collection and combustion of biogas from landfills. Biogas is a complex mixture of gases formed from organic waste as a result of microbial activity. Maintenance work on the project requires a capital investment in gas gathering system and the purchase of equipment for the combustion of methane. The project will reduce the risk of pollution for residents of areas in the immediate vicinity of the existing landfills. Landfills are located in the municipalities of central Serbia (Uzice, Pozega, Cacak). These municipalities, along with six other municipalities in the area of Zlatibor agreed to establish a new landfill. Hence, these existing landfills will be out of action for the next three years.

This project activity would involve investments in gas collection systems and equipment for methane flaring. The project will also reduce environmental risks for the residents in the vicinity of the existing disposal sites.

It is estimated that the project can reduce emissions through flaring of captured landfill gas of nearly $140,000 \mathrm{t} \mathrm{CO}_{2 \mathrm{eq}}$ in total for the period 2008-2018, or given split to each dump site 52,000 t $\mathrm{CO}_{2 \mathrm{eq}}$ in Uzice, 24,000 t $\mathrm{CO}_{2 \mathrm{eq}}$ in Pozega and 64,000 t $\mathrm{CO}_{2 \mathrm{eq}}$ in Cacak.

In recent times, there has been a greater use of biogas extracted from landfills and wastewater. Even if it is not used for thermal and electrical energy, the landfill gas must be properly disposed and cleaned, because it contains harmful combustible elements, many of which form smog. Biogas digesters use biodegradable materials, of which two useful products are obtained: biogas and high quality fermented bio fertilizer. Biogas 
filtered to the level of purity for pipelines is called renewable natural gas, and it is possible to use it on every occasion in which natural gas is used. This includes transport of gas through pipelines, electricity production, space and water heating, and in many technological processes. Compressed biogas can be used to power motor vehicles.

The basic production process of biogas mainly consists of three parts:

- Preparation of biological input;

- Degradation;

- Waste treatment.

Biogas (and biomass) is renewable energy source with low amounts of carbon. If used properly, biomass is sustainable fuel that can considerably influence the decrease of carbon net emissions compared with other fossil fuels.

Although burning of biogas and natural gas leads to the creation of certain amounts of carbon-dioxide $\left(\mathrm{CO}_{2}\right)$, carbon in the biomass originates from plant mass, which contains carbon from atmospheric carbon dioxide. Thus, the use of biogas is viewed as $\mathrm{CO}_{2}$ neutral and does not influence the greenhouse effect with the increased amounts of gases.

Further conclusion can be drawn from the fact that the substitute of fossil fuels for biogases brings a decrease of $\mathrm{CO}_{2}$ emissions.

Carbon, which is present in biomass of approximately $50 \%$ of its dry matter, is already a part of atmospheric cycling of carbon. Plants absorb $\mathrm{CO}_{2}$ from the atmosphere during its entire life cycle. At the end of the plant life cycle, the same carbon returns to the atmosphere as a mixture of carbon dioxide and methane. Methane is transformed into carbon dioxide in the atmosphere, and in this way the cycle is completed. The burning of biomass and biogases, whether direct or indirect, as a fuel, also releases $\mathrm{CO}_{2}$ into the atmosphere. Of course, this $\mathrm{CO}_{2}$ is part of the cycle of carbon in the atmosphere.

The international waste management company A.S.A. had built the landfills for communal waste, all completely in accordance with the European standards. Landfill in Lapovo was put in operation in 2009. It is currently in the procedure for approving the regional plan for waste management, after which landfill will officially acquire the status of a regional landfill, pursuant to current laws. It was built to accept all waste coming from that region, so that it may also be put at the disposal of some other municipalities, such as Novi Becej, Zitiste and others. The project development will run parallel to the implementation of investments because this project is being implemented in phases. According to the plan, what follows is the construction of new cassettes for the landfill and waste management centre, which will be equipped with new waste treatment lines.

Table 1. The CDM Projects of biogas plants in Serbia [18]

\begin{tabular}{|c|c|}
\hline Proposer of the project & Project title \\
\hline Biogas power plant Alibunar & Biogas power plant Alibunar \\
\hline Nucleus Center Ltd. & Biogas Plant Raca \\
\hline Bionersis SA & Collection of landfill gas at landfill Valjevo \\
\hline Camco Carbon International Ltd. & Alibunar biogas plant construction project \\
\hline Amest SRL & $\begin{array}{l}\text { LFG recovery and electricity production at the Bubanj } \\
\text { landfill site, Nis, Serbia }\end{array}$ \\
\hline "Lazar" Ltd. & Dairy "Lazar" Biogas Project \\
\hline Alltech Fermin & $\begin{array}{l}\text { Energy utilization of methane obtained from } \\
\text { improved wastewater treatment in Alltech Fermin, } \\
\text { Senta, Serbia }\end{array}$ \\
\hline PKB "IMES" Comp. & $\begin{array}{l}\text { "Pigs for kilowatts" - management of animal waste } \\
\text { and obtaining energy, Belgrade, Serbia }\end{array}$ \\
\hline
\end{tabular}


The landfill Vrbak in Lapovo spans nearly 22 hectares. A.S.A. Vrbak renders services of communal waste collecting and disposal for the municipalities of Lapovo, Batocina, Despotovac and Raca, whereas Topola only disposes of its waste at this landfill. A.S.A. Eko in Serbia offers services of waste collecting, treatment and disposal to citizens and municipalities, and there is also a special set of services such as maintenance of green areas, road management and cleaning, winter and summer maintenance of roads, etc. Among the users are companies, small entrepreneurs and market chains that either outsource or directly use the services of waste management, which is, in such chains, primarily related to secondary raw materials.

\section{THE PROJECTS OF SMALL HYDROPOWER PLANTS IN SERBIA}

Stocks of renewable energy resources in Serbia are high. For example, the number of favourable sites on the rivers for the construction of small hydropower plants, according to experts, is more than eight hundred.

However, permission to build small hydropower plants has been given to about 60 projects. Very often, the work on the project is suspended because of difficulties in obtaining permission based on the assessment of environmental impact. In addition, a significant problem is the financing of the construction and purchase of equipment. Not all projects are covered with matching funds $[19,20]$.

In cooperation with 17 municipalities in Serbia, the Ministry of Energy has prepared a tender for the release of 317 seats for the construction of mini hydropower plants in Serbia.

According to data from the Cadastre of small hydropower plants on the territory of Serbia without autonomous province Vojvodina, Serbia has the potential to build 856 small hydropower plants (100 kW to $10 \mathrm{MW)} \mathrm{[21].} \mathrm{The} \mathrm{total} \mathrm{hydropower} \mathrm{potential,} \mathrm{gross}$ potential water which flow through watercourses on the territory of the Republic of Serbia amounted to $25,000 \mathrm{GWh} /$ year. The largest part of the hydropower potential of over $70 \%$ is concentrated in only a few watercourses with a potential of over 1,000 GWh/year: the Danube, Drina, Velika Morava, Lim and Ibar. The other rivers' potential will only be able to partially take advantage of the priority of the water management of water use, as because some rivers are planned as a source of regional water systems: Toplica, Crni Timok, Rasina, Studenica, Veliki Rzav, Mlava, Lepenac, etc.

Table 2. The Projects of small hydropower plants in Serbia [18]

\begin{tabular}{ll}
\hline Proposer of the project & Project title \\
\hline IGIS IMAKO Ltd. & Construction of small hydropower plant "Gornjak“ \\
IGIS IMAKO Ltd. & Construction of small hydropower plant "Metovnica" \\
IGIS IMAKO Ltd. & Construction of small hydropower plant "Ribare“ \\
IGIS IMAKO Ltd. & $\begin{array}{l}\text { Construction of small hydropower plant "Zlot" } \\
\text { Construction of small hydropower plant "Prevalje" }\end{array}$ \\
IGIS IMAKO Ltd. & $\begin{array}{l}\text { Construction of small hydropower plant "Jelašnica" } \\
\text { IGIS IMAKO Ltd. }\end{array}$ \\
IGIS IMAKO Ltd. & $\begin{array}{l}\text { Construction of small hydropower plant "Drvnik" } \\
\text { Construction of small hydropower plant "Mezdreja" } \\
\text { EcoEnergo Group Ltd. }\end{array}$ \\
$\begin{array}{l}\text { River in Crna Trava } \\
\text { Construction of a system of small hydropower plants on Ljutina } \\
\text { river }\end{array}$ \\
\hline HIDRO ONE Ltd.
\end{tabular}


Technically exploitable potential in Serbia is around $19.8 \mathrm{TWh} /$ year, of which 17.5 $\mathrm{TWh} / \mathrm{year}$ in facilities larger than $10 \mathrm{MW}$. The total technical potential of hydro power plants up to $10 \mathrm{MW}$ is estimated to be about $1,800 \mathrm{GWh}$ per year. The remaining technical hydropower potential and the possibility of its utilization will be determined in accordance with the criteria of non-energy related to multipurpose use of water and on the basis of political agreement on the sharing of hydropower potential with neighboring countries. Today work is being done on a detailed audit of location, to produce a more manageable list of the locations and create a better planning basis for the use of renewable sources.

This year, 2014, Serbia is beginning the construction of small hydropower plants on waterways in 156 locations.

\section{CONCLUSION}

In the Republic of Serbia, there is a need for the implementation of projects that help the environment protection. One of the goals of environmental protection is the reduction of greenhouse gas emissions according to the Kyoto Protocol. This goal can be reached, among others, by the implementation of CDM projects.

The success of these projects is crucial for further implementation of the Environmental Strategy of the Republic of Serbia, not only at national level, but also at the local level throughout the Republic of Serbia. The CDM projects have a positive impact on the environment, in particular about the mitigation of global climate change and local environmental sustainability. The CDM (Clean Development Mechanism) project activity in the Republic of Serbia involves bundling of three dump sites in order to give added value to the envisaged method of the environmentally sound closure of the dump sites. Currently, the closing procedure envisages only covering with a soil layer, leaving the possibility to consider other measures depending on waste and landfill characteristics. The added value of the project refers to enabling LFG (Landfill gas) collection and flaring at the sites. Through flaring, the methane is converted into $\mathrm{CO}_{2}$ and hence, the greenhouse gas effect is reduced. This project activity would involve investments in gas collection systems and equipment for methane flaring. The project will also reduce environmental risks for the residents in the vicinity of the existing disposal sites.

Bundled dump sites are situated in Central Serbia, of which Uzice and Pozega in Zlatibor District, and Cacak in the Morava District. These municipalities together with six other municipalities in the Zlatibor District agreed to found a new regional sanitary landfill and the existing dump sites should be put out of operation within next three years.

The implementation of CDM projects contribute to the use of other renewable energy sources: wind power (wind turbines, wind farms), water energy (small hydro plants), solar energy (solar panels, photovoltaic systems), synthesis of biofuels from biomass, etc.

In accordance with the resolution, this will contribute to an increasing interest in the use of solar panels on the roofs of buildings. The duration of stimulating measures is 12 years.

Since the production of electricity from renewable resources in most cases is more expensive than energy production from fossil fuels, the so-called support systems have been introduced, i.e. financial and nonfinancial measures of incentives to invest in facilities that use renewable energy.

The intensive exploitation of the renewable resources must become one of the important goals of economic development in Serbia. 


\section{ACKNOWLEDGEMENTS}

This study is part of the Interdisciplinary research projects III 47009 and III 43009 which are supported by the Ministry of Education, Science and Technological Development of Serbia in the period 2011-2014.

\section{REFERENCES}

1. Kyoto Protocol to the United Nations Framework Convention on Climate Change, United Nations, 1998.

2. Report on the Progress in the Implementation of the National Sustainable Development Strategy of Serbia for 2010, the Government of the Republic of Serbia. Agency for Environmental Protection, September 2011 (in Serbian)

3. National Strategy of Sustainable Development for the period 2009-2017, Official Gazette of the Republic of Serbia, No 57/08 (in Serbian)

4. Law on Ratification of the Amendment to Annex B of the Kyoto Protocol to the UN Framework Convention on Climate Change, Official Gazette of the Republic of Serbia, No 36/09 (in Serbian)

5. Law on Environmental Protection, Official Gazette of the Republic of Serbia, No 135/04 and 36/09 (in Serbian)

6. Law on Spatial Plan of the Republic of Serbia in Period 2010-2020, Official Gazette of the Republic of Serbia, No 88/10 (in Serbian)

7. National Strategy for the inclusion of Serbia into Clean Development Mechanism, for waste management, agriculture and forestry, Official Gazette of the Republic of Serbia, No 30/10 (in Serbian)

8. First National Report of the Republic of Serbia under the Framework Convention on Climate Change, Government of RS, 2011 (in Serbian)

9. United Nations Framework Convention on Climate Change, United Nations, 1992.

10. Gazette of Electrical Network of Serbia, EMS, Vol. 62, 2013 (in Serbian)

11. Jovanović, L. and Tomić, A., The implementation of renewable energy sources as a condition of energy efficiency in Serbia, Ecologica, Vol. 62, pp. 234-239, 2011 (in Serbian)

12. Jovanović, L., Tomić, A., Cvijić L., Implementation and promotion of the Sustainable development strategy of the Republic of Serbia till 2020 year, Ecologica, Vol. 66, pp.173-177, 2012 (in Serbian)

13. Munitlak-Ivanović, O. and Golušin, M., Concept, characteristics and condition of sustainable development indicators in selected countries of South East Europe, Ecologica, Vol. 63, pp. 355-362, 2011 (in Serbian)

14. Regulation on incentives for the privileged electrical energy producers, Official Gazette of the Republic of Serbia, No 8/13 (in Serbian)

15. http://www.energetskiportal.rs [Accessed: 06-Sep-2013]

16. Donevska, K., Jovanovski, J., Jovanovski, M., Pelivanoski, P., Analyses of Environmental Impacts of Non Hazardous Regional Landfills in Macedonia, Journal of Sustainable Development of Energy, Water and Environment Systems, Vol. 1, No. 4, pp. 281-290, 2013., http://dx.doi.org/10.13044/j.sdewes.2013.01.0021

17. Eto, R., Murata, A., Uchiyama, Y., Okajima, K., Assessment of Co-benefits of Clean Development Projects Based on the Project Design Documents of India's Power's Sector Currently under Registration and Validation, Journal of Sustainable Development of Energy, Water and Environment Systems, Vol. 1, No. 4, pp. 326-339, 2013., http://dx.doi.org/10.13044/j.sdewes.2013.01.0025 
18. National Authority for the implementation of the Clean Development Mechanism of the Kyoto Protocol (DNA), http://80.93.243.155/DNA/?lang=src [Accessed: 26-Feb-2013] (in Serbian)

19. Golušin, M., Dodić, S., Vučurović, D., Ostojić, A., Jovanović, L., Exploitation of Biogas Power Plant - CDM Project, Vizelj, Serbia, Journal of Renewable and Sustainable Energy, Vol. 3, No. 5, 052701, pp. 1-11, 2011., http://dx.doi.org/10.1063/1.3631820

20. Golušin, M., Dodić, S., Vučurović, D., Jovanović, L., Munitlak-Ivanović, O., Sustainable Energy Management in Industry of the Republic of Serbia, Biogas Power Plants Advantages, Industrija, Vol. 40, No. 4, pp. 107-124, 2012.

21. Land Registry of small hydro power plants in Serbia, EnergoprojectHydroengineering, 1991, Belgrade. 